H. X. REN ${ }^{1}$, Sh. Q. LIU' ${ }^{*}$, X. C. ZHANG ${ }^{1}$, and Y. J. ZENG ${ }^{2 *}$

\title{
SPIKE TIMING-DEPENDENT PLASTICITY IN THE CA1 PYRAMIDAL NEURON IN A MODELED HIPPOCAMPAL CIRCUIT
}

\author{
Received March 12, 2014
}

Spike timing-dependent plasticity (STDP) plays an important role in sculpting informationstoring circuits in the hippocampus, since motor learning and memory are thought to be closely linked with this classical plasticity. To further understand the information delivery in a hippocampus circuit, we build a computational model to study the potential role of linear changes in the synaptic weight and synaptic number. Several key results have been obtained: (i) Changes in the synaptic weight and numbers lead to different long-term modification; (ii) the first paired spiking from two neurons significantly influences the adjusted subsequent paired spiking; the pre-post spiking pair strengthens the following paired spiking; however, the post-pre spiking pair depresses the subsequent spiking; (iii) when the synaptic weight and synaptic numbers are changed, the interval of the first spiking pair may undergo reduction, and (iv) when we stimulate a stellate neuron weakly or decrease the capacitance of CA1 pyramidal neuron, LTP is more easily produced than LTD; on the contrary, LTD is more easily produced in an opposite situation; increase in the synaptic numbers can promote activation of the CA1 pyramidal neuron.

Keywords: computational model, hippocampus, neuronal circuits, spike timingdependent synaptic plasticity (STDP), synaptic weight and number.

\section{INTRODUCTION}

Since the discovery of persistent enhancement of the efficacy of synaptic transmission by tetanic stimulation in the hippocampus [1], i.e., a phenomenon now generally called long-term potentiation (LTP), studies of the activity-dependent synaptic plasticity became one of the scientific frontiers and hot topics in neurobiology $[2,3]$. Subsequent studies have further addressed the importance of the temporal order of presynaptic and postsynaptic spiking for long-term modifications in a variety of glutamatergic synapses and have defined "critical windows" for spike timing. When presynaptic spiking in neuronal pairs precedes postsynaptic spiking (the situation hereafter referred to as "pre-post") within a window of several tens of milliseconds, LTP is induced, whereas spiking of the reverse order ("post-pre") leads to LTD. This form of activity-dependent LTP/LTD is now referred to as

\footnotetext{
${ }^{1}$ Department of Mathematics, South China University of Technology, Guangzhou, China.

${ }^{2}$ Biomedical Engineering Center, Beijing University of Technology, Beijing, China.

${ }^{*}$ Correspondence should be addressed to Sh. Q. Liu or Y. J. Zeng (e-mail: yjzeng@bjut.edu.cn).
}

spike timing-dependent plasticity (STDP) [4].

In their early experiments, Levy and Steward [5] examined the effect of relative timing of presynaptic and postsynaptic action potentials (APs) at the millisecond level on the plasticity phenomena. A later work, by Bi and Poo [6], underscored the importance of precise spike timing, synaptic strength, and postsynaptic cell type in activity-induced modifications of the efficacy of central synapses. These authors suggested that Hebb's rule may need to incorporate a quantitative consideration of spike timing that reflects a narrow and asymmetric window for the induction of synaptic modification. Recently, studies of STDP in in vivo systems were carried out, and several layers of complexity in STDP were revealed [7]. According to the mathematical fitting method of exponential function [6], a computational model was built to investigate biophysical mechanisms by which storage and recall of spatio-temporal input patterns are achieved by the CA1 microcircuitry [8].

On the basis of the real connection system between different cells in a hippocampus circuit, we, using computational approaches, studied the interaction of different inputs, as well as the STDP learning rule, which were influenced by changes 
in the synaptic strength and synaptic number in different combinations. In addition, some meticulous potentiation and depression phenomena can be reached at the same time.

\section{METHODS}

Taking into account the results of anatomy studies on the system of connections between cells and physiological parameters of each cell, we constructed a simplified computational hippocampus network that is rather similar to the real system and includes three kinds of neurons present in the rat hippocampal network, namely CA1 pyramidal neurons, stellate neurons, and CA3 pyramidal neurons. In order to simulate real neuronal properties in this circuit, we used only three neurons to build the circuit, where the perforant path projects to the hippocampus from the entorhinal cortex. This pathway forms excitatory synapses on the apical dendrites of the CA1 pyramidal neuron. The CA3 pyramidal neuron is connected with the CA1 pyramidal neuron, which also shapes excitatory synapses through a set of fibers called Schaffer collaterals [9] (Fig. 1).

According to the results of real biological experiments, it is rather easy to understand the configuration of the examined hippocampus circuit. The sequence of events in such circuit is also very specific. The inevitable physiological parameters in this model related to every neuron can be obtained from the respective papers $[9,10]$ and the Appendix.

In theoretical analysis, a single cell can be characterized as relying on the conduction model and the compartment model; different parts of the neuron can be described by different compartment numbers. The basic theory of electrical signal transmission is

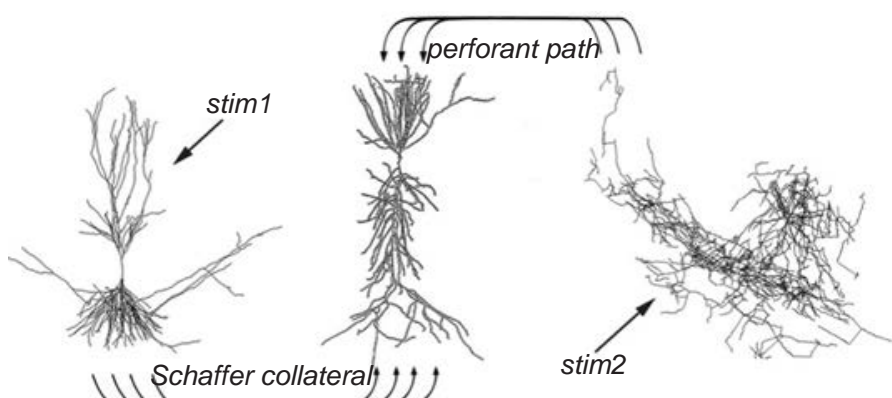

CA3 pyramidal cell CA1 pyramidal cell EC stellate neuron cell

F i g. 1. Schematic model of a hippocampus circuit including $C A 3$ and CA1 pyramidal neurons and an EC stellate neuron.

Р и с. 1. Схема модельованої гіпокампальної нейронної мережі. based on the Rall's cable model, and its discrete format is a neuronal compartment model [11-14]. We should notice that different compartments have different ion channels and some initial ion variables. The parameters and neuronal equations can be described as follows:

$$
\left\{\begin{array}{l}
C \frac{d V}{d t}=I_{\text {ion }}+I(t)+I_{\text {compartment }}+I_{s y n} \\
\frac{d x}{d t}=\left(x_{\infty}-x\right) / \tau_{x}
\end{array}\right.
$$

In the neuronal equations shown above, $C, x=x(V)$, $I_{\text {compartment }}$, and $I_{\text {syn }}$ separately indicate the cell membrane capacitance, the channel open or closed, the external stimulus, compartment currents, and synaptic currents. Chemical synapses provide connections between the cells, and different connections can be described as excitatory or inhibitory [14].

The network was constructed within the framework of the NEURON software, and we used MATLAB software to process the data. The simulated results have been repeatedly verified.

\section{RESULTS}

In the language of neuroscience, synaptic plasticity is the ability of a connection or a synapse between two neurons to change its efficacy (strength) in response to either use or disuse of transmission over synaptic pathways [15]. Here, we simulated the two situations: (i) The synaptic conductance of NMDA receptors is the product of 0.035 and the synaptic weight; the synaptic conductance of AMPA receptors is the product of 0.001 and the synaptic weight. Thus, a linear change in the synaptic weight is analogous to a linear change in the synaptic conductance. (ii) Linear change in the number of synapses can be provided.

Here, we will give a description of a "normalized EPSP slope," $k$. Under initial conditions, the first spike of the postsynaptic neuron is marked V0. If we change the prerequisites, the postsynaptic neuron will generate a new first spike marked V1. In such a way, we can calculate the "normalized EPSP slope"

$k=(\mathrm{V} 1-\mathrm{V} 0) / \mathrm{V} 0$.

LTP and LTD Produced in the CA1 Pyramidal Neuron by Perforant Path Synapses. Results of the previous research [16] showed that direct sensory 
information arriving at distal CA1 synapses through the perforant path provide compartmentalized instructive signals that assess the saliency of mnemonic information propagated through the hippocampal circuit to proximal synapses. Here, we mainly analyze the impact of perforant path synapses.

At the beginning, we only stimulated the stellate cell with a constant input, and there was no input from Schaffer collaterals to the CA1 pyramidal neuron. When the synapse weight is initially small, the system is always in the pre-post firing pattern, and the critical window shows that the LTP phenomenon shown in the experiment is observed [17]. The first spiking pair interval demonstrates a tendency toward a decrease when the synaptic weight increases (Fig. 2A). If we increase the synaptic weight to a greater value, the system is always in the post-pre firing pattern, where LTD can be reached (C).

When the synapse number is initially small, the system also shows a pre-post firing pattern. If we increase the synaptic number to 51 , when the system is always in the pre-post firing pattern, the critical window provides the LTP phenomenon (Fig. 2B). On the contrary, when the synapse number is decreased to 54 from a greater number, the LTD phenomenon can also be formed (D).

During LTP, the first spiking pair is regarded as
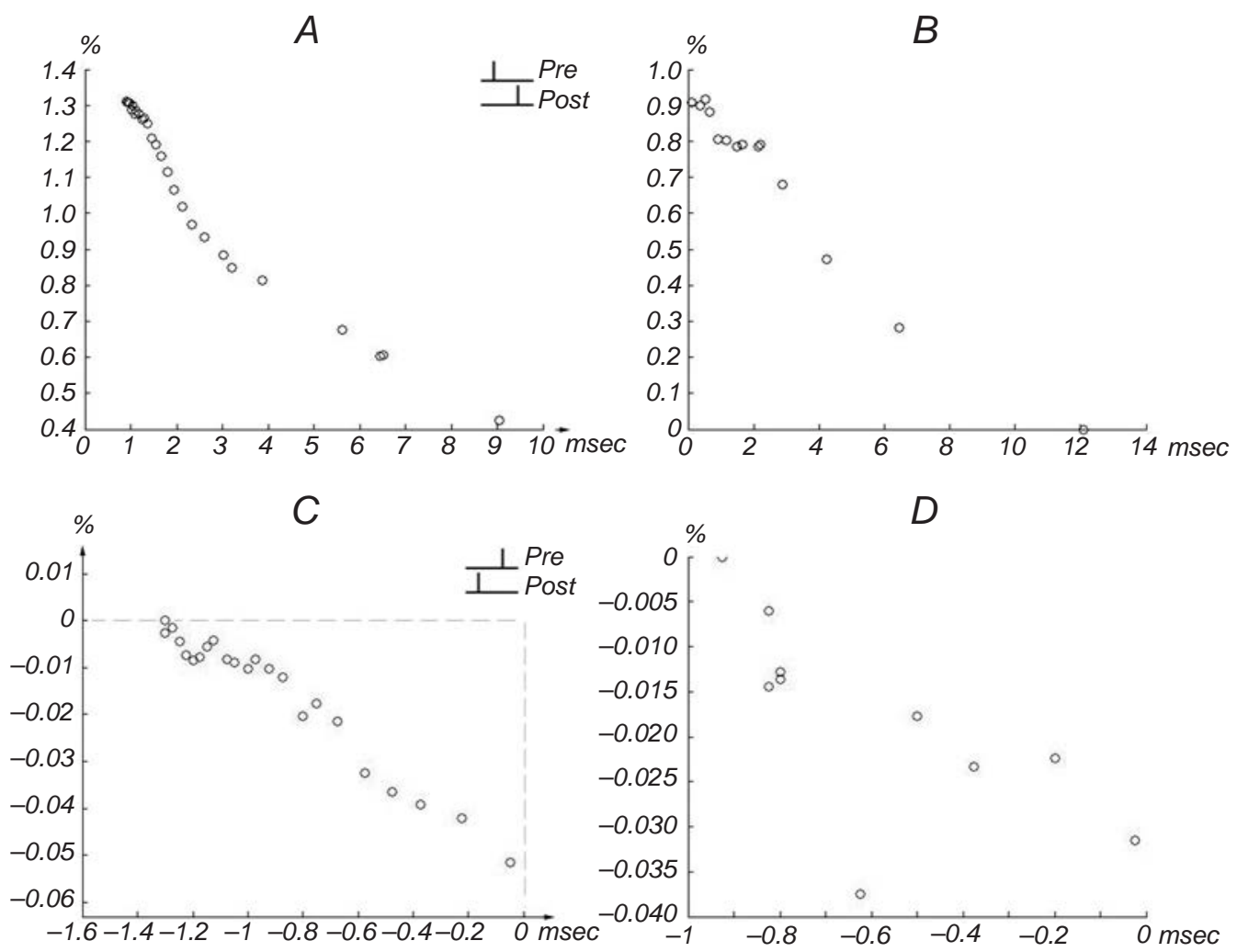

playing a dominant role to restrict the subsequent postsynaptic spiking. The first pre-post spiking pair can intensify the subsequent paired spiking; nevertheless, potentiation would recede when the firing interval decreases (Fig. 3A, B). During LTD, however, an opposite conclusion can be reached (C, D).

According to the computational simulation, changes of both synaptic weight and synaptic number would lead to the replacements of LTP and LTD. But how the two long-term changes are related to storing and delivering information is quite difficult to prove. Moreover, the computational results can inspire us to test and simulate the various factors that can be introduced in the biological experiments to complete the STDP theory with extreme difficulties.

LTP Produced in the CA1 Pyramidal Neuron by Schaffer-Collateral Synapses. Clarke and Stephen [18] showed that selective induction of different forms of LTP is achieved via spatial segregation of functionally distinct calcium signals, where activation of NMDA receptors is necessary. So, we studied the impact of Schaffer-collateral synapses on the CA1 pyramidal neuron to further understand the mechanisms of synaptic plasticity.

Here, we also stimulated the $C A 3$ pyramidal neuron via a constant input. In a manner similar to that

F i g. 2. Critical window. Abscissa) Post-pre interval, msec; ordinate) normalized EPSP slope, \%. The perforantpath synaptic number $(\mathrm{N})$ and weight (W) are the following: A) $\mathrm{N}=60, \mathrm{~W}$, from 0.08 to $0.35 ; B) \mathrm{W}=0.5, \mathrm{~N}$ from 15 to 51 ; C) $\mathrm{N}=60$, W from 1.45 to 0.4 , and $D) \mathrm{W}=0.5, \mathrm{~N}$ from 81 to 54 .

Р и с. 2. Критичне вікно. 


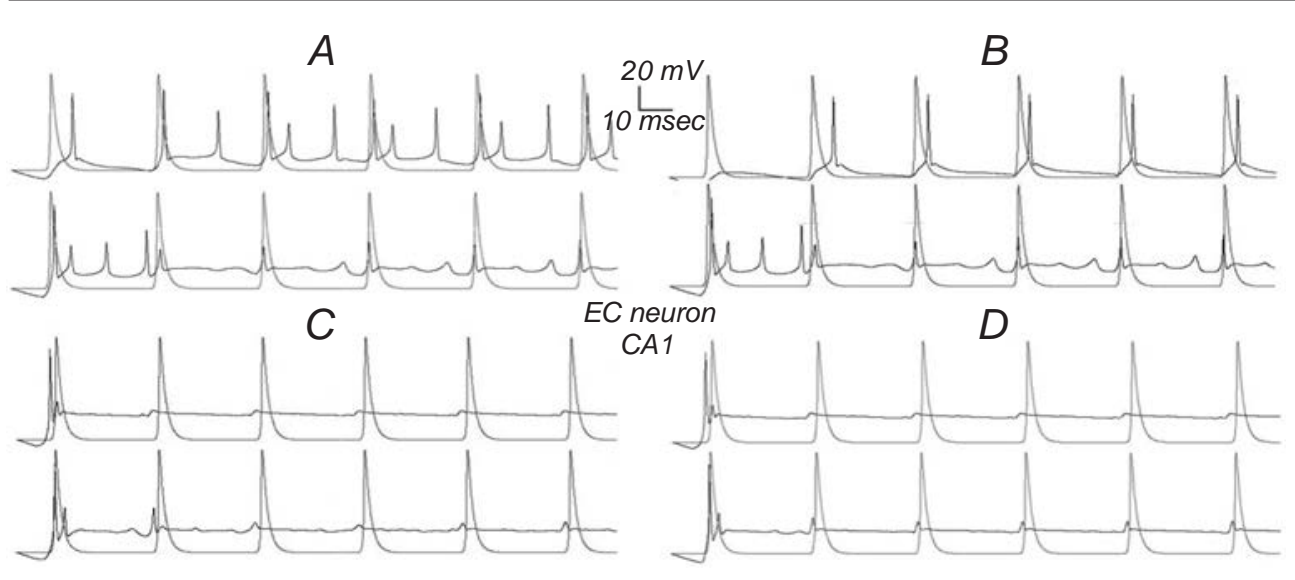

F i g. 3. The first spiking pair restricts subsequent post-synaptic spiking. The perforant-path synaptic weight (W) and number (N) are as follows: A) top 0.2 and 36 , bottom 0.5 and 36 ; B) top 0.5 and 12 , bottom 0.5 and 36 ; C) top 0.7 and 96 , bottom 0.2 and 96 , and $D$ ) top 0.8 and 96 , bottom 0.8 and 48 . Red line shows the firing pattern of the stellate neuron; black line shows that of the CA1 pyramidal neuron.

P и с. 3. Генерація першої пари піків обмежує генерацію наступних постсинаптичних піків.

described above, we studied the impact of Schaffercollateral synaptic weight and synaptic number on the phenomena observed. We found only LTP induced by increase in the synaptic weight and synaptic number (Fig. 4). Both the effect of the first spiking pair and the trend of spiking intervals are rather similar to the results shown above. The difference is that we failed to find the post-pre pattern of the first spiking pair interval, which can induce LTD.

From the aforementioned research, we acquired some properties of LTP and LTD and are able to summarize their difference and similarity. The difference mainly relates to the initial state, the magnitude of the first spiking pair interval, and the effects of these factors (a detailed description was presented above). The similarity is that the magnitude of the first spiking pair interval demonstrates a decreasing trend, in both LTP and LTD. Transformation of the role of the first spiking depends on the synaptic weight and number of synapses. The smaller the synaptic weight and the mentioned number, the more obvious the inhibitory function. We should, however, note that the first firing interval also depends on the synaptic weight and synaptic number. We found that when the interval in the first spiking pair decreases, the peak voltage in the CA1 pyramidal neuron also decreases, and this mode of inhibition depends on firing of the presynaptic stellate neuron; the less pre-bursting spikes, the more obvious the inhibitory function (Fig. 5).

Factors that can Affect the Firing Pattern of the First Spiking. Based on the former analyses, we studied the factors that can influence the firing pattern of the first spiking. When the synaptic weight is high initially, LTD is induced with decrease in the synaptic weight. On the contrary, when the synaptic weight is small initially, LTP is induced with increase in the synaptic weight. But we should pay special attention to the critical value differentiating LTD and LTP.

From the simulated graph of the relationship between the critical value and the external stimulus intensity, it is easy to find that when the latter parameter (stimulus

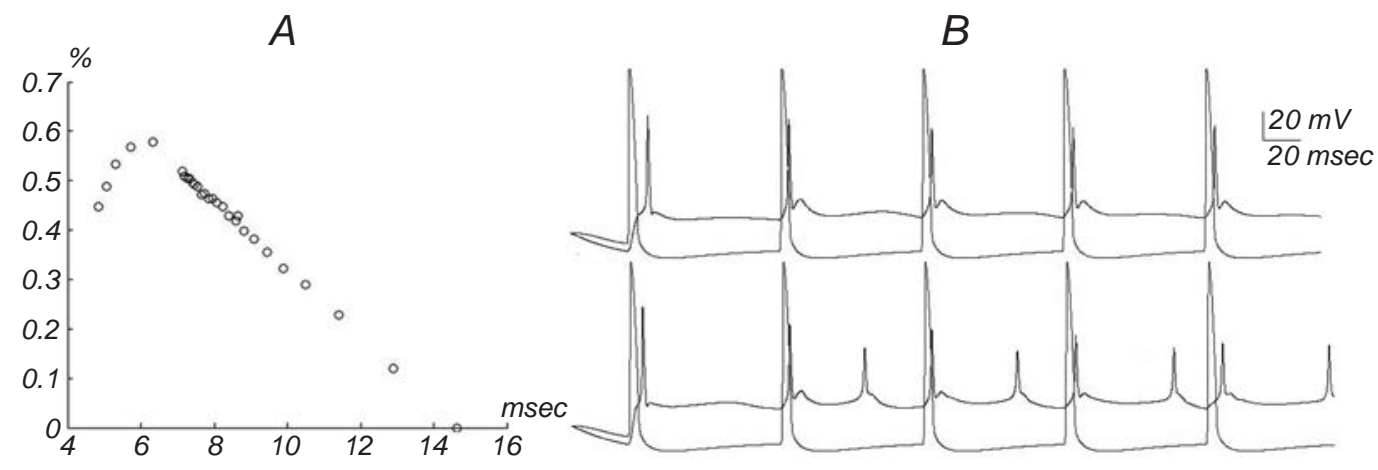

F i g. 4. Critical window. A) The Schaffer-collateral synaptic number is 48 , the synaptic weight is from 0.2 to 3 ; B) the first spiking pair restricts the subsequent postsynaptic spiking; blue line is firing of the CA3 pyramidal neuron, and black line is that of CA1 pyramidal neuron. The Schaffer-collateral synaptic weight and synaptic number are as follows: the top one)synaptic weight 0.7 , synapse number 54; the bottom one) synaptic weight 1.4, synapse number 54 .

Р и с. 4. Критичне вікно $(A)$ та обмеження наступної активації пірамідного нейрона САЗ генерацією першої пари піків $(B)$. 
A B

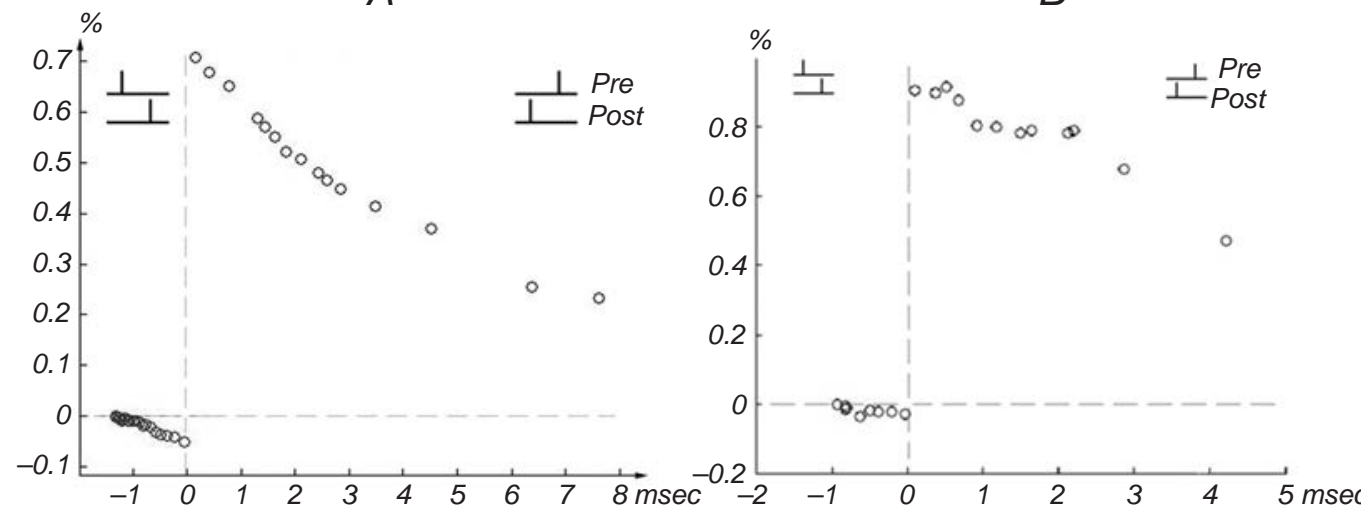

\section{C}
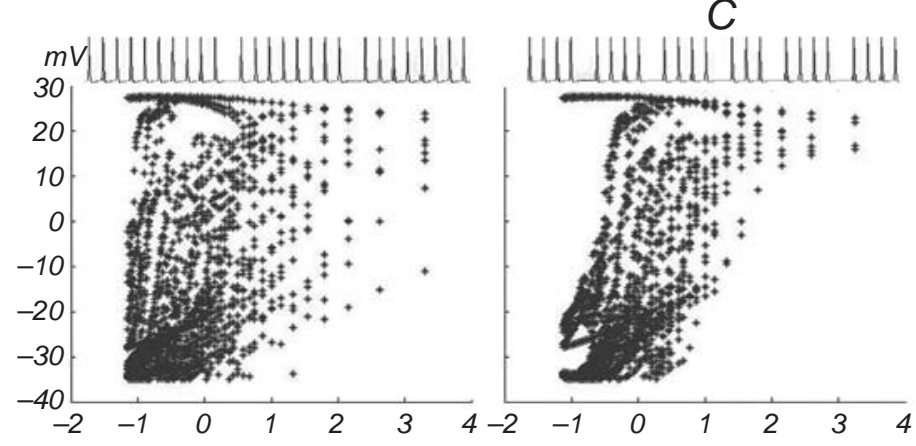

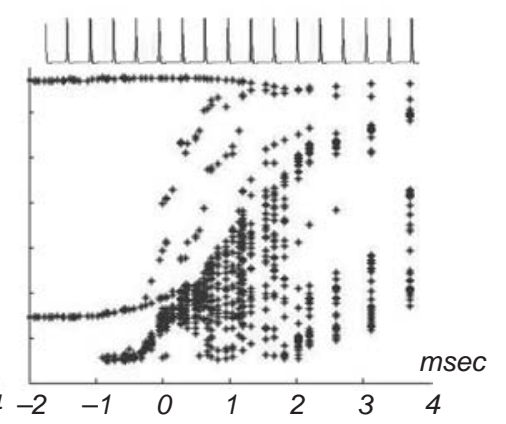

F i g. 5. Relationships: $A$ and $B$ ) Between the first spiking interval and induction of LTD vs. LTP and relationship between the peak voltage in the CA1 pyramidal neuron and the first spiking interval at different firing patterns of the presynaptic stellate neuron $(C)$.

P и с. 5. Відношення між інтервалом у першій парі піків та індукцією тривалих депресії та потенціації. intensity) increases, the critical value will decrease. Then we continued to study the relationship between the critical value and the membrane capacitance of the CA1 pyramidal neuron. We found that when the membrane capacitance increases, the critical value will increase. In other words, LTP was more easily induced than LTD with a larger membrane capacitance of the CA1 pyramidal neuron or a weak external stimulus input (Fig. 6).

The Function of Schaffer-Collateral Synapses on the CA1 Pyramidal Neuron. Jarsky et al. [13] have examined the function of those distal synaptic
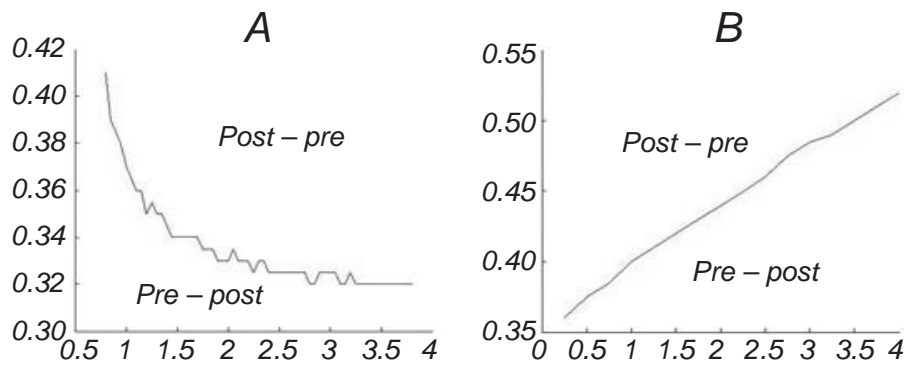

F i g. 6. Relationships of the critical value between two patterns and the external stimulus intensity $(A)$ and of the critical value between the two patterns and the membrane capacitance of the CA1 pyramidal neuron $(B)$.

Р и с. 6. Відношення між критичною межею двох патернів та інтенсивністю зовнішнього стимулу $(A)$ та ємністю мембрани пірамідного нейрона $C A 1(B)$. inputs, which led to three predictions confirmed in the experiments using rat hippocampal slices. On the basis of the above research, we primarily studied the function of Schaffer-collateral synapses on the CA1 pyramidal neuron.

In our model, the CA1 pyramidal neuron has only connections with the stellate neuron. The latter receives a constant external stimulus, and we can estimate the relationship between necessary synaptic number and synaptic weight. To study how the Schaffer-collateral inputs affect this relationship, we connected the CA3 pyramidal neuron with the CA1 pyramidal neuron once again. The necessary synaptic number decreased in the presence of both inputs, in contrast to the situation without the Schaffercollateral input. The latter input could better promote the efficiency of activation of the CA1 pyramidal neuron (Fig. 7A). Then we fixed synaptic weights and saw that activation of the CA1 pyramidal neuron was promoted by increasing the numbers of the two abovementioned kinds of synapses (B).

Then, we analyzed the influence of Schaffercollateral synapses on the perforant path by changing the perforant path synaptic weight and examined the LTD and LTP reproduction again. Nevertheless, the range of $k$ is very narrow in the case of LTD and the change of $k$ is wider in the case of LTP than that without the stimulus applied to Schaffer collaterals 


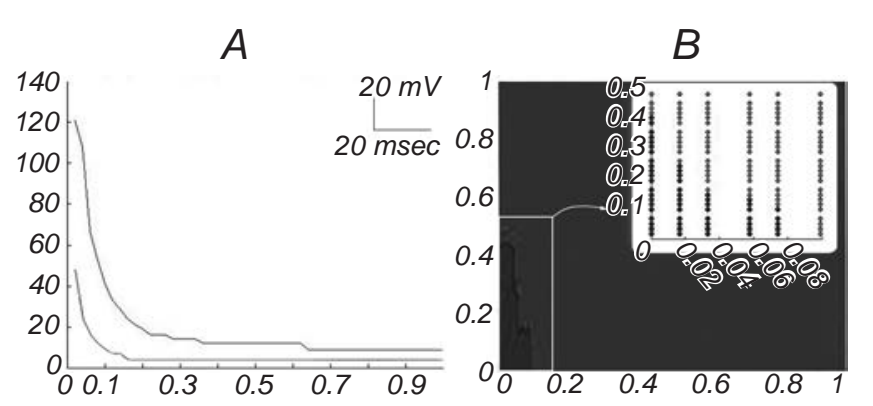

F i g. 7.Relationship of the perforant-path synaptic weight and the necessary synaptic number. A) Blue line is that with only the perforant-path stimulus, and red line is that with both perforant-path and Schaffer-collateral stimuli; $B$ ) activation of the CA1 pyramidal neuron would be promoted by increasing the numbers of the above two kinds of synapses; blue points represent the cases where the CA1 pyramidal neuron failed to be activated, and red points represent the opposite situation.

P и с. 7. Відношення між синаптичною вагою входів перфорантного шляху та необхідною кількістю синапсів.

(Fig. 8A, B).

Based on the role at the first spiking pair we have discussed above, we can conclude that, in the case where the first spiking pair corresponds to the prepost firing pattern, subsequent presynapse spiking can promote firing of the postsynaptic unit via perforantpath synapses. However, such promotion decreases after firing of the CA3 pyramidal neuron even though LTP is expected to be induced in Schaffer-collateral synapses (Fig. 8C).

Therefore, we mainly studied the interaction of the two synaptic systems on the CA1 pyramidal neuron and the phenomenon of synaptic plasticity by studying mechanisms of the hippocampus circuit modeled considering the firing pattern qualities. A few results stemming from the subsequent discussion were obtained:

Changes in the synaptic weight and synaptic number between the CA1 pyramidal neuron and the stellate neuron lead to long-term changes in the CA1 pyramidal neuron, which include LTD and LTP. The first spike of the postsynaptic neuron (CA1 pyramidal neuron) plays an important role in modifying the subsequent spiking. The pre-post firing pattern plays a positive role in facilitating the following spiking. On the contrary, the post-pre firing pattern plays a negative role in this respect.

Changes in the synaptic weight and synaptic number between the CA1 pyramidal neuron and the CA3 pyramidal neuron lead only to LTP in the former (CA1 pyramidal) neuron. When we change the synaptic weight, the first spiking pair interval is reduced, which directly inhibits changes in the first spiking pair.

When we apply a weak external stimulus to the EC stellate neuron or decrease the capacitance of the CA1 pyramidal neuron, LTP is more easily to be produced than LTD; in the opposite situation, LTD is more readily to be produced than LTP. In addition, Schaffer collaterals can better promote activation of the CA1 pyramidal neuron; however, their activity inhibits potentiation of the first spiking pair.
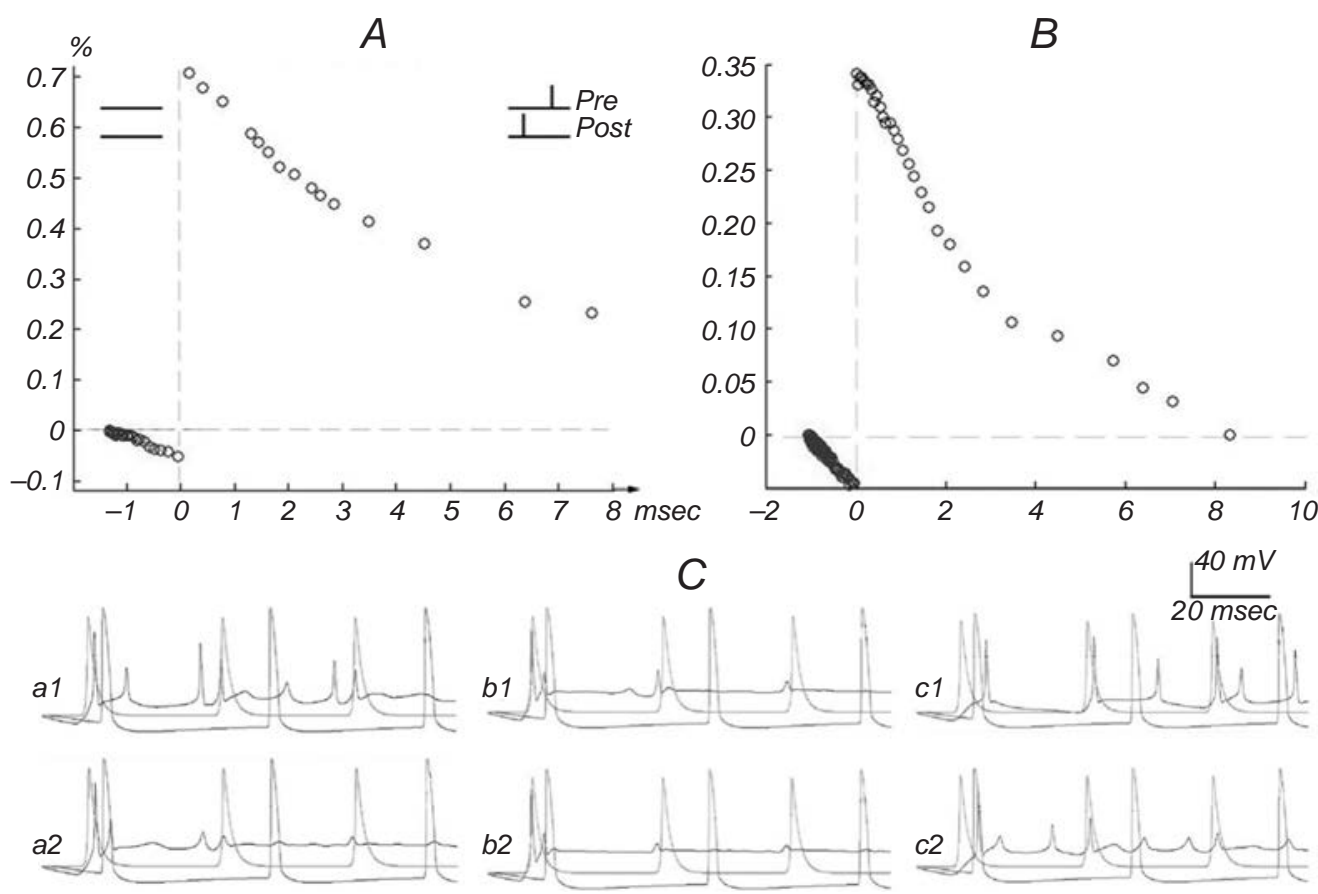

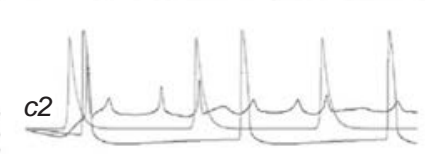

F i g. 8. Induction of LTP and LTD under different conditions. A) Only with perforant-path stimulus, LTP and LTD procedure (black dots and blue dots); B) with both perforant-path stimulus and Schaffer-collateral stimulus, and $C$ ) firing patterns of different neurons, those of the CA3 pyramidal neuron (blue), stellate neuron (red), and CA1 pyramidal neuron (black).

P и с. 8. Індукція довготривалих потенціації та депресії при стимулюванні тільки перфорантного шляху $(A)$ та цього шляху й колатералей Шафера $(B)$. 
Based on the above analyses, the constructed hippocampal network possesses a clear network configuration and is able to realize many functions. In this paper, we mainly discuss the synapse modification due to linear changes of the synaptic number and weight and also to interactions between the perforant path inputs and Schaffer collateral inputs. In fact, some results obtained in our study are rather similar to the results of biological experiments. Since general learning rules are too complex to be extracted from the results of the above experiments, the results of model computation will provide further significant help in future research.

Appendix. Supporting information. Supplementary data associated with this article is in the online version at http:// neuromorpho.org/ and http://senselab.med.yale.edu/modeldb/.

This publication was not associated with any experiments on animals or tests involving human subjects; therefore, it does not require confirmation of compliance with existing ethical standards from this aspect.

The authors of this communication, H. X. Ren, Sh. Q. Liu, X. C. Zhang, and Y. J. Zeng, confirm the absense of any conflict related to comercial or financial interests, to interrelations with organizations or persons in any way involved in the research, and to interrelations of the co-authors.

\section{Х. Кс. Рен}

\section{ПЛАСТИЧНІСТЬ, ЗАЛЕЖНА ВІД ЧАСУ ГЕНЕРУВАННЯ ПІКІВ, У ПІРАМІДНОМУ НЕЙРОНІ СА1 МОДЕЛЬНОЇ ГІПОКАМПАЛЬНОЇ НЕЙРОМЕРЕЖІ}

${ }^{1}$ Південно-Китайський технологічний університет, Гуанчжоу (Китай).

\section{${ }^{2}$ Центр біомедичного інженірінга Пекінського} технологічного університету, Пекін (Китай).

P е 3 ю м е

Пластичність, залежна від часу генерування піків (spike timing-dependent plasticity - STDP), відіграє важливу роль у формуванні нейромереж, що накопичують інформацію в гіпокампі; вважається, що моторне навчання та пам'ять тісно пов'язані з пластичністю цього типу. Для глибшого розуміння процесів передачі інформації в гіпокампальній нейромережі ми створили комп'ютерну модель, щоб вивчити потенціальну роль лінійних змін синаптичної ваги та числа синапсів у таких мережах. Було отримано чотири основні результати: 1) зміни ваги та числа синапсів можуть призводити до появи різних феноменів довготривалої модифікації; 2) перша пара потенціалів дії, генерована двома нейронами, істотно впливає на характеристики другої пари піків; генерація пари піків у пре-пост-послідовності полегшує генерацію наступної пари, тоді як пост-прегенерація пари пригнічує генерацію наступної пари; 3 ) коли вага синапсів та їх кількість змінюються, інтервал у першій парі піків зменшується; 4) коли стимулювати зірчастий нейрон 3 невеликою інтенсивністю або зменшити ємність пірамідного нейрона CA1, легше індукується довготривала потенціація; у протилежній ситуації легше виникає довготривала депресія; збільшення числа синапсів полегшує активацію пірамідного нейрона CA1.

\section{REFERENCE}

1. T. V. Bliss and T. Lomo, "Long-lasting potentiation of synaptic transmission in the dentate area of the anaesthetized rabbit following stimulation of the perforant path," J. Physiol., 232, 331-356 (1973).

2. R. C. Malenka and S. A. Siegelbaum, Synaptic Plasticity, Johns Hopkins Univ. Press (2001).

3. S. J. Martin, P. D. Grimwood, and R. G. Morris, "Synaptic plasticity and memory: an evaluation of the hypothesis," Annu. Rev. Neurosci., 23, 649-711 (2000).

4. Y. Dan and M. M. Poo, "Spike timing-dependent plasticity: from synapse to perception," Physiol. Rev., 86, 1033-1048 (2006).

5. W. B. Levy and O. Steward, "Temporal contiguity requirements for long-term associative potentiation/depression in the hippocampus," Neuroscience, 8, No. 4, $791-797$ (1983).

6. G. Q. Bi and M. M. Poo, "Synaptic modifications in cultured hippocampal neurons: dependence on spike timing, synaptic strength, and postsynaptic cell type," J. Neurosci., 18, No. 24, 10464-10472 (1998).

7. C. Natalia and Y. Dan, "Spike timing-dependent plasticity: A Hebbian learning rule," Annu. Rev. Neurosci., 31, 25-46 (2008).

8. C. Vassilis, C. Stuart, and P. G. Bruce, "Encoding and retrieval in a model of the hippocampal CA1 microcircuit," Hippocampus, 20, 423-446 (2010).

9. M. Royeck, M. T. Horstmann, S. Remy, et al., "Role of axonal NaV1.6 sodium channels in action potential initiation of CA1 pyramidal neurons," J. Neurophysiol., 100, No. 4, 2361-2380 (2008).

10. H. Peter, E. Daniel, B. Angela, et al., "Distinct classes of pyramidal cells exhibit mutually exclusive firing patterns in hippocampal area CA3," Hippocampus, 18, No. 4, 411-424 (2008).

11. W. M. Yamada, C. Koch, and P. R. Adams, Multiple Channels and Calcium Dynamics, MIT Press, Cambridge (1987).

12. M. Migliore and G. M. Shepherd, "Dendritic action potentials connect distributed dendrodendritic microcircuits," J. Comput. Neurosci., 24, 207-221 (2008).

13. R. Michel, M. T. Horstmann, R. Stefan, et al., "Role of axonal $\mathrm{Na} V 1.6$ sodium channels in action potential initiation of CA1 pyramidal neurons," J. Physiol., 4, 2361-2380 (2008).

14. L. Wang and S. Q. Liu, "Neural circuit and its functional roles in cerebellar cortex," Neurosci. Bull., 27, 3, 173-184 (2011).

15. J. R. Hughes, "Post-tetanic potentiation," Physiol. Rev., 38, No. 1, 91-113 (1958).

16. T. D. Joshua, T. David, and A. S. Steven, "A role for synaptic inputs at distal dendrites: Instructive signals for hippocampal 
long-term plasticity,” Neuron, 56, 866-879 (2007).

17. J. Tim, R. Alex, L. K. William, and S. Nelson, "Conditional dendritic spike propagation following distal synaptic activation of hippocampal CA1 pyramidal neurons," Nat. Neurosci., 8, 1667-1676 (2005).

18. R. R. Clarke and J. P. Stephen, "Spatial segregation of neuronal calcium signals encodes different forms of LTP in rat hippocampus," J. Physiol., 570, No. 1, 97-111 (2006).

19. T. Jarsky, A. Roxin, W. L. Kath, and N. Spruston, "Conditional dendritic spike propagation following distal synaptic activation of hippocampal CA1 pyramidal neurons," Nat. Neurosci., 8, No. 12, 1667-1676 (2005). 